\title{
The Framework Modelfor the Implementation of Collaborative and Interactive Learning in the University Classroom
}

\author{
Mohammed Alhaji Mohammed ${ }^{1 *}$, Adel A. Abdou ${ }^{2}$ \\ ${ }^{1}$ Department of Architectural Engineering, King Fahd University of Petroleum and Minerals \\ Dhahran, Saudi Arabia \\ ${ }^{2}$ Department of Architectural Engineering, King Fahd University of Petroleum and Minerals \\ Dhahran, Saudi Arabia \\ *Corresponding author's email: mamkol [AT] yahoo.com
}

\begin{abstract}
Today, colleges and universities recognize that, to employ and retain good students and highest level of academic staffing for the best student comprehension, the provision of contemporary and highly equipped instructional facilities is essential. This paper discusses the impact of the indoor environmental quality; the instructional technology; the physical set up of the university classroom; and the emerging teaching/learning pedagogies on students' performance. It is established that, these four factors have a significant effects on st udent learning outcome. The study also presents a comprehensive and criticalreview of literat ure on the nature of the university classroom for collaborative and interactive learning, with the aim of providing an enabling environment of higher learning in the universities. The research suggests that improving the three influential components i.e. the indoor environmental quality, the instructional technology and the physical set up will help in enhancing student performance and productivity. The study concluded by establishing a systematic framework model for the implementation of collaborative and interactive learning in the university classroom.
\end{abstract}

Keywords - University Classroom; Collaborative and interactive learning; Instructional technology; Equipment; Learning styles; Physical set up; Learning outcome; Students; Environment.

\section{INTRODUCTION}

A class roomis an environment intended for the teaching and learning activities in a safe at mos phere with out any interruption or distraction. The exchange of Information between learners and teacher in a classro om u sually happens through the two basic media of vocal and visual communication. These communication processes require a le arning environment facilitated with the right visual, acoustic, and thermal qualities for the effective exchange of knowledge and an enhanced levelof comprehension. The University classrooms hould accommodate the ba sic modern technology and resources for eas y pedagogical delivery, and offer a flexible layout that can reflect the specific learning styles of the teacher. Today, colleges and universities recognize that the precondition to employing and retaining good st u den ts and academic teams is the availability of modern and well-res ourced instructional facilities. Furthermore, owing to therecent changes in learning styles as a consequence of emerging technology, an efficient modern university classroom, su itable to these changing styles, with a state-of-the-art educational facilities and a comfortable indoor environment is essential.

Moreover, there is an increase desire for a collaborative and interactive learning environment bet ween university students and ins tructors, which demands the provision of suitable layouts to accommodate such instructional pe d agogy. Despite rapid development in technology, which supports and enhances collaborative and interactive learning, it wo u ld appear that the bulk of clas srooms in today's universities fail to reach thesestandards [26]. For thes e de velop ments to reach the clas srooms, a framework model for the implementation of a collaborative and interactive learning en vironment is required.

\section{RESEARCH METHODOLOGY}

In order to accomplis h the study objectives, the following research methodology is implemented.

a) A comprehensive literature review has been conducted to address the main issues with regard to the in fluential factors affecting collaborative and interactive learning in the univ ersity classroom.

b) A thorough analysis of the collected literature has been conducted to ascertain the relationship between the influential factors, which affect student performance, and their achievement in the university classroom.

c) Based on the analyses of the above two stages, a conclusion has been reached with the establishment of a model framework for the implementation of a collaborative and interactive learning en vironment. 


\section{INFLUENTIAL FACTORS AFFECTING STUDENT LEARNING IN THE UNIVERSITY CLASSROOM}

\subsection{Classroom Indoor Environmental Quality (IEQ)}

\subsubsection{Lighting Quality}

Lighting is, and always has been, an important factor in the design and operation of educational spaces. As electric power costs declined and designers began to take advantage of the increased flexibility provided by electric lighting, daylighting took a secondary role [4]. "A major challenge is to provide classroomlighting that will increas e teach er control, reduce glare, improve lighting and optimize visual comfort whils t minimizing the ligh ting power and energy use to their lowest possible levels" [33]. Heschong Mahone Group [17; 18] found and validated respectively a compelling statis tical correlation between the amount of daylight in the elementary school clas sroom and the performance of $s$ tudents on standardized math and reading tests. The studies of the classrooms als o showed that the position of windows and the resulting lighting quality in the classrooms are a key is sue in learning, and can have both positive and negative impacts on student performance. Another study conducted by the New Building Institute, [31] also expands and validates previous research carried out by Heschong Mahone Group [17].

\subsubsection{Acoustic Quality}

Acoustic comfort in the classroomremains a crucialfactor in development activities, particularly those that require a high level of students' attentiveness [22]. The effects of clas sroomacoustics on learning outcomes are well establis he d, reliable and substantial, demonstrating that high-quality clas sroomacoustics are funda mental to student achieving outstanding results [36]. It has been establis hed that, a high level of background noise and reverberation in the classroom, adversely affects the learning setting, especially for young children, who need optimal situations for hearing and understanding [41]. Moreover, the design of an environment, which enables enhanced, appropriate and accurate hearin g, is vital for students' comprehension. Earthman, [9] cited many studies linking the acoustic environment in a clas s room to academic achievement, thus relating levels of classroom noise and reverberation to reading and spelling ability, behaviour, attention, s pace concentration, and student comprehension. The ability to clearly hear and comprehend what is being taughtis a prerequisite for effective learning. The impairment of this ability through unwanted noise will decrea se student performance. Benjamin et al [3] confirm that exterior and interior noise sources are among the major contributors of acoustic dis comfort in the classroom.

\subsubsection{Thermal comfort}

The relationship between thermal comfort and student performance in classroom has been established in the literature. Ed Young, et al. [10], study links classroom indoor thermal comfort to student educational outcome. The efficiency of student performance in clas sroom is largely dependent on the nature of the thermal environment, as a comfortable thermal environment leads to an outstanding student performance [9]. Temperature, humidity and air movement all affect the thermal environment in classroom. An increase in temperature in any workplace tends to decrease worker efficiency and consequently increase work related accidents [9].

\subsubsection{Indoor Air Quality}

The effect of poor indoor air quality on student performance remain s one of the contin uous questions in educatio nal facilities res earch. Many studies have linked poor indoor air quality to illnes ses leading to student absence in school and a direct reduction in the person's capacity to perform specific mental assignments which require concentration, calculation or memory [12]. Some research established the lack of acceptable evidence linking poor air quality in clas srooms to low student performance [29]. However, Wargocki, and Wyon, [44] in their studies agreed EPA [12] th at, poor indoor airquality, can lead to absenteeismdue to the effect of chemicals in circulation which affect asthma and increase res piratory dust. Ed Young, et al. [10] establis hed the exis tence of the relationship between the indoor air quality and student health and achievement, as serting that Poor indoor air quality cau ses res piratory infections, wors ens allergies, and causes drowsiness and a shorter attention span. Furthermore, Shaughnessy et al. [37] confirmed these associations in their studies linking clas sroomventilation rates to student performance in math standardized test s cores, stre ssing the need for further studies with a larger sample size and a broader assessment of the indoor environment. With the ab ove affirmations there is therefore enough evidence linking indoor air quality to student performance in the clas sroom.

\subsection{Classroom Physical Set-up and Geometrical Configuration}

The physical set-ups in educational facilities have a great impact on student comfort, achievements and the gen eral clas sroomcommunication process. The effectiveness in communication in the clas sroom, which is partially a function of seating arrangements, is vital to the success of both the student and teacher [27]. Ed Young, et al. [10] in their studies as certained that s tudents had higher achievement scores in the newer facilities compared to their scores in the older ones. The study outcome confirms that, the newer the facilities the higher the scores in reading, mathematics, and composition clas ses. The improvement in facility conditions leads to improved student achievement and scores, just as stimulating set- 
ups promotepositive attitudes in students [10]. The suitability orotherwise of furniture and the seating arrangement largely depends on the learning sty les employed in the clas sroom.

Moreover, the size of the clas sroomis also an es sential factor to be considered in school design as this will have an effect on the educational outcome. The study by Public Agenda indicated that $70 \%$ of the teachers surveyed believed that a small class size is more important to student performance than a smaller schoolsize [36]. Classroomsizes are u sually determined by the expected seating capacity, for example computer clas srooms generally require 2.8-3.7 squ are meters perstudent, also the provision of a sufficient space for an instruction area to accommodate the instructor's wo rks tation; the environmental controls; the projector; screen; white board and a technology storage space is also essential [11].

\subsection{The Impact of Information and Com munication Technology (ICT) in the Classroom}

Information and Communication Technology (ICT) varies from lower to higher technology with the potential of enhancing learning practices through many approaches and which impact on the students learning and in structors teaching. The establishment of enough s pace for computers and supporting facilities (e.g. printers, network connections and large monitors), initiates the instructor's reorganization process. This will result in a re-as sessment of clas sroo m activities and an enhanced efficiency in the learning experience [15]. The incorporation of information and communication technology in the classroom systembegan more than two decades ago, with the application of new technology, such as email, Internet, the W orld Wide W eb and video-conferences. These applications have ge nerated fresh communication possibilities for the teaching and learning process of such things as emails and video-conferences [19]. Today, ICT potential involves the teaching of technical and cognitives kills to access, utilize, develop, cre ate, an d communicate information effectively with ICT tools. Learners in classrooms express this expertise by applying technology decisively to solve problems, analyse and exchange information, develop ideas, create models, and cont rol devices [1].

\subsection{Classroom Seating Arrangem ent Styles}

The nature of the classrooms eating arrangement is one of the core characteristics to be considered in de sig ning the clas sroomfor collaborative and interactive learning. Franklin, [14], studied the "L" shaped classroomwhich may offer the flexibility beneficial to the multidimensional elementary classroom of the future. Emmons and Wilkinson [11] classified classroom design into three models including the "demo" for passive audience presentation; the "lab" for practical work; and the classroom that combines elements of the two. The need for student collaboration and interaction during the learning process is one of the most important considerations in adopting a particular seating arran geme $\mathrm{nt}$ in the clas sroom. The typical characteristics of the collaborative and interactive classroominclude visual contact a mo ngst students, an ease in forming small groups, and flexible and reconfigurable furniture.

\section{REQUIREMENTS OF THE UNIVERSITY CLASSROOM}

The classroomratio of 20 to 25 students is considered best for collaborative and interactive le arning, and it als o reduces student rowdiness. According to the study conducted by Kokkelenberg, et al [20], student scores de cre ases significantly as class size increases until class sizes of twenty, are reached and more slowly, still markedly through larger clas s sizes. Hence, a s mall, eas y to control, clas sroom size is necessary to achieve the required pedagogical outcome. Due to the large number of facilities/equipment required to support interactivity in the collaborative classroom, an exp anded instructor space for the use of an interactive dis play is required. Apart from the instructor's chair, the instructor's space also houses the Information and Communication Technology (ICT) corner, which constitutes the gadgets required to set up interactivity; internet accessories; multimedia equipment; and other remote collaborativetools. The pro vis ion of a raised access floor in a collaborative and interactive clas sroomprovides a void forcables, ducts and other un der floor services. The floor panels can be raised with appropriate lifting devices to accommodate theinstallation of extra services when necessary [2]. This provides opportunity for the reorganization of furniture in the classroom without any dis traction to suit the particular collaborative situation.

Furthermore, as different pedagogical techniques require different types of learning space, it is not cost effective to provide different clas srooms for different pedagogical requirements, flexible, adjustable and movable furniture has to be provided in the collaborative and interactive clas sroom. A survey has shown that almost half of the instructors prefer the movable seating arrangement [32].The mobility of the furniture provides a means for the student to manoeuvre the furniture as required for the pedagogical style operating in the classroomat any point in time.

\section{COLLABORATIVE AND INTERACTIVE LEARNING PEDAGOGY}

The importance of the Learning and teaching style in the university classroom instructional delivery cannot be overemphasized. A Learning style is a unique and habitual mode of acquiring knowledge, skills and attitudes by study or experience [38]. Prior to the discussion on collaborative and interactive learning, it is relevant to acknowledge the existence of other learning and teaching styles that are also applicable in the collaborative settings. There are man y well defined learning styles prominent in the literature; Kolb [21] come up with four sets of learning styles, Mu ir [30] cited eleven learning styles as shown in Table 1., Teaching styles according to Contias cited in McCoy, [28] refer to an y 
cons istent ins truction practices employed by a teacher irres pective of the situation or the content being taught. They are divided into two, including the teacher-centred approach and learner-centred approach. Teacher-centred approach is the one in which the teacher is active throughout the session, the students remain passive lis teners and learner-centred approach is the opposite when the students are actively involved. These teaching and learning styles need to be considered when designing, upgrading and enhancing any classroomin order to avoid both ins truction and assimilation conflict that will decrease performance. Table 1 shows various learning styles descriptions and models.

Collaborative learning provides an environment which stimulates and augments the learning process through the introduction of interactive settings and by creating a pragmatic atmosphere, into the classroom which enriches the effectiveness of the system. Such an environment willas sist in sustaining the student intere st by providing a more pragmatic learning habitation [8]. Collaboration learning is an active process and a coordinated effort by which learn ers pursue joint objectives, solve problems, and build a common understanding of a particular is sue [25]. The medium of collaborative learning provides students with opportunities to analyse, synthesize, and evaluate ideas cooperatively [16]. Owing to the benefits attached in engaging teamlearners collaboratively in problem-solving activities, students n eed to interact socially and develop the essential intellectual structures to acquire their own knowledge. Collaborative le arn ing us ually enhances social skills and facilitates student participation in their social structure, whilst conveying the relevance of learning. Moreover, it als o permits more student-centred educational processes, requires less discipline and is more stimulating [39]. The encouragement of collaborative learning in the university clas sro om should move beyond the student level, and involve course teachers who should be well-informed. Hence, teachers have to be supported and ins pired in adopting and implementing the transformation, froman is olated teaching model, to a collaborative le arn ing one.

Moreover, the success of collaborative learning depends considerably on the availability of the suitable in structional, physical, and socialconditions. Simply grouping people and requesting them to execute tasks or solve problems does not necessarily encourage the kind of interaction that increases the learning possibility, rather collaboration should be understood in a wider sense [26]. In order to be effective and successful in problemsolving, it is es sential that knowledge is constantly shared and constructed in teams [24]. Empirical studies indicated that collaborative learning is ofte $n$ more effective than individual learning, depending on the quality of interactions during collaboration [7].

Furthermore, the study conducted by Leidner, and Fuller, [23] found that students working collaboratively in grou ps have a greater interest in materials and perceive themselves to learn more than students working individually. The students in a collaborative group are responsible for an equal work distribution to ensure the adequate con tribution of each member leading towards achieving the required goal and effective as sessment of all components. Hence, students as comment on each other's work or ideas, they are als o assessing their own understanding within a new context [34]. The collaborative and Interactive learning en vironment should be equipped with all the necessary to ols th at $\mathrm{c}$ an allow for remote interactivity inclu ding Tele-collaboration, video-conferencing, Smart-Board, software tools, and internet facilities etc. to enable physical en gagement of various formats of s ynchronous-collaborative classes [43].

Table 1: Learning styles Descriptions and Models

\begin{tabular}{|c|c|c|c|}
\hline $\mathbf{S} / \mathbf{N}$ & Learningstyles & Description/Comments & Models/Inventor \\
\hline 1. & $\begin{array}{l}\text { Diverging learning } \\
\text { style }\end{array}$ & $\begin{array}{l}\text { Feeling and Watching, } \\
\text { Work in group (brainstorming) }\end{array}$ & \multirow{4}{*}{$\begin{array}{l}\text { The four Kolb } \\
\text { learning styles [5] }\end{array}$} \\
\hline 2. & $\begin{array}{l}\text { Assimilating learning } \\
\text { style }\end{array}$ & $\begin{array}{l}\text { Watching and Thinking } \\
\text { Reading, Lectures, and Exploring analytical models. } \\
\text { Less focus on people }\end{array}$ & \\
\hline 3. & $\begin{array}{l}\text { Converging learning } \\
\text { style }\end{array}$ & $\begin{array}{l}\text { Doing and Thinking } \\
\text { Less concern with people } \\
\text { Prefer technical task } \\
\text { Experiment, simulate and practical applications. }\end{array}$ & \\
\hline 4. & $\begin{array}{l}\text { Accommodating } \\
\text { learning style }\end{array}$ & $\begin{array}{l}\text { Doing and Feeling } \\
\text { Hands-on learners } \\
\text { Rely on others for information } \\
\text { Works in teams trying different ways. }\end{array}$ & \\
\hline 5. & $\begin{array}{l}\text { Visual (spatial) } \\
\text { learning style }\end{array}$ & $\begin{array}{l}\text { Seeing and Reading in observation. } \\
\text { Pictures, diagrams, demonstrations, display, hand-outs, and films. }\end{array}$ & \multirow[t]{3}{*}{$\begin{array}{l}\text { The VAK learning } \\
\text { styles model [5] }\end{array}$} \\
\hline 6. & $\begin{array}{l}\text { Auditory learning } \\
\text { style }\end{array}$ & Listening and Speaking & \\
\hline 7. & Kinesthetic learning & $\begin{array}{l}\text { Touching and Doing } \\
\text { Physical experience }\end{array}$ & \\
\hline 8. & $\begin{array}{l}\text { Sensing and intuitive } \\
\text { perception }\end{array}$ & $\begin{array}{l}\text { Sensors are practical and inductors are imaginative. } \\
\text { Sensors like facts \& observations, and inductors like concept \& } \\
\text { interpretation. }\end{array}$ & \\
\hline
\end{tabular}




\begin{tabular}{|c|c|c|c|}
\hline 9. & $\begin{array}{l}\text { Visual and verbal } \\
\text { input }\end{array}$ & $\begin{array}{l}\text { Visual learners get info from visual images. } \\
\text { Pictures, diagrams, graphs, schematics \& demonstrations. } \\
\text { Verbal learners get info from verbal material, written \& spoken } \\
\text { words, and math formulas. } \\
\text { A lecture is verbal while experiment is visual. }\end{array}$ & \multirow{4}{*}{$\begin{array}{l}\text { The dichotomous } \\
\text { learning style } \\
\text { dimensions of this } \\
\text { model [13]. }\end{array}$} \\
\hline 10. & $\begin{array}{l}\text { Inductive } \\
\text { deductive } \\
\text { organization }\end{array}$ & $\begin{array}{l}\text { Inductive learners use observation, experiment \& numerical } \\
\text { Science instructions are deductive. } \\
\text { Deductive is more conscience \& orderly than inductive }\end{array}$ & \\
\hline 11. & $\begin{array}{l}\text { Active and reflective } \\
\text { processing }\end{array}$ & $\begin{array}{l}\text { Active learners learn by doing \& work well in group } \\
\text { Reflective learners use to think and work alone or in pairs. } \\
\text { Most lecture classes do very little for the two }\end{array}$ & \\
\hline 12. & $\begin{array}{l}\text { Sequential and global } \\
\text { understanding }\end{array}$ & $\begin{array}{l}\text { Sequential learners absorb information and acquire understanding of } \\
\text { material in small connected chunk. } \\
\text { Global learners take in information in seemingly unconnected } \\
\text { fragments and achieve understanding in large holistic leaps. }\end{array}$ & \\
\hline 13. & Activitist s (Do) & $\begin{array}{l}\text { These are 'hands-on' learners } \\
\text { Immerse themselves fully in new experiences } \\
\text { Enjoy here and now } \\
\text { Open minded, enthusiastic, flexible } \\
\text { Acts first, consider consequences later } \\
\text { Seek to centre activity around themselves }\end{array}$ & \multirow{4}{*}{$\begin{array}{l}\text { Honey and } \\
\text { Mumford Model } \\
\text { learning [40]. }\end{array}$} \\
\hline 14. & Reflectors(Review) & $\begin{array}{l}\text { These are 'tell me' learners } \\
\text { Stand back and observe } \\
\text { Cautious, take a back seat } \\
\text { Collect and analyse data about experience and events, slow to reach } \\
\text { conclusions } \\
\text { Use information from past, present and immediate observations to } \\
\text { maintain a big picture perspective. }\end{array}$ & \\
\hline 15. & Theorists (Conclude) & $\begin{array}{l}\text { These are 'convince me' learners } \\
\text { Think through problems in a logical manner, value rationality and } \\
\text { objectivity } \\
\text { Assimilate disparate facts into coherent theories } \\
\text { Disciplined, aiming to fit things into rational order } \\
\text { Keen on basic assumptions, principles, theories, models and system s } \\
\text { thinking }\end{array}$ & \\
\hline 16. & Pragmatists (Plan) & $\begin{array}{l}\text { These are 'show me' learners and want a demonstration. } \\
\text { Keen to put ideas, theories and techniques into practice } \\
\text { Search new ideas and experiment } \\
\text { Act quickly and confidently on ideas, gets straight to the point } \\
\text { Are impatient with endless discussion. }\end{array}$ & \\
\hline 17. & $\begin{array}{l}\text { Concrete Sequential } \\
\text { Learner }\end{array}$ & $\begin{array}{l}\text { Direct hands on activities } \\
\text { Active (tactile) methods } \\
\text { Use Workbooks, diagrams, flowchart and demonstrations for } \\
\text { instruction. } \\
\text { Computer assisted instructions }\end{array}$ & \multirow{4}{*}{$\begin{array}{l}\text { Anthony Gregorc } \\
\text { learning styles on } \\
\text { brain [35]. }\end{array}$} \\
\hline 18. & $\begin{array}{l}\text { Concrete } \quad \text { Random } \\
\text { Learner }\end{array}$ & $\begin{array}{l}\text { Prefer trial \& error approach. } \\
\text { Independent study, computer games, simulations, multimedia \& } \\
\text { software. }\end{array}$ & \\
\hline 19. & $\begin{array}{l}\text { Abstract } \\
\text { Learner }\end{array}$ & $\begin{array}{l}\text { Verbal, logical \& analytical approach. } \\
\text { Like written, verbal \& visual instruction. } \\
\text { Lectures, reading, outlines, conducting Internet searches, email, list } \\
\text { serves, and audiotapes. }\end{array}$ & \\
\hline 20. & $\begin{array}{l}\text { Abstract } \quad \text { Random } \\
\text { Learner }\end{array}$ & $\begin{array}{l}\text { Responds to visual instruction. } \\
\text { Group discussion \& face to face meetings } \\
\text { Uncomfortable with distance education } \\
\text { Instructional methods: video clips, group discussion, } \\
\text { videoconferencing, television, case studies, chat-rooms, and guest } \\
\text { speakers. }\end{array}$ & \\
\hline 21. & Verbal (Linguistic) & $\begin{array}{l}\text { Involves both written and spoken words } \\
\text { Public speaking, debating, politics, writing \& journalism. }\end{array}$ & \multirow{4}{*}{ Other Models } \\
\hline 22. & Logic (mathematical) & $\begin{array}{l}\text { Use logic \& reasoning, as in sciences, mathematics, accounting, } \\
\text { detective work, law \& computer programming. }\end{array}$ & \\
\hline 23. & Social (interpersonal) & $\begin{array}{l}\text { Prefer to learn in group } \\
\text { Communicate both verbally \& non verbally well }\end{array}$ & \\
\hline 24. & $\begin{array}{l}\text { Solitary } \\
\text { (intrapersonal) }\end{array}$ & $\begin{array}{l}\text { Prefer to work alone } \& \text { use self-study } \\
\text { More private \& independent }\end{array}$ & \\
\hline
\end{tabular}




\section{FRAMEWORK MODEL FOR IMPLEMENTING COLLABORATIVE AND INTERACTIVE LEARNING IN UNIVERSITY CLASSROOM}

The success, or otherwise, of any collaborative and interactive learning process in the university classroom depen ds largely on the quality of the implementation method. The strategies to be employed in s et ting ou t an y collab orative layout should be in line with the learning style adopted in the classroom. The framework model for the implementation of collaborative and interactive learning in the university classroom has been developed as follows:

\subsection{Identify the collaborative learning style to be adopted in the classroom}

The identification of a particular learning style to be adopted in pedagogical delivery is the first step for the implementation of collaborativelearning in the classroom. Many learning styles exist in the lite rature as presented in Table 1. The identification and subsequent selection of the learning style is done based on the requirement of the course and the material to be taught as some courses require the pragmatic approach in which activities will be de mo n strated practically in the clas sroom, other styles are logical in nature and require reasoning and tho roug $\mathrm{h}$ dis cussion a mo $\mathrm{ng}$ students and their ins tructor. Therefore, care should be taken when deciding on which type of learning style is to be applied in the collaborative and interactive classroom.

\subsection{Determine the requirements for the selected collaborative learning style}

Depending on the nature of pedagogical delivery required by the selected collaborative learning s ty le, there is a pos sibility of providing the wrong requirement for the selected learning style. Selected learning styles for collab orative and interactive learning should be premeditated and understood clearly prior to assigning any requirement for its proper delivery, e.g. s ome learning styles require voting equipment in form of clickers, while others require flipch art etc.

\subsection{Determine the classroom size required to accom modate the requirements above}

The consideration of the classroomsize in relation to the learning style requirement is very important. The various facilities, the equipment and materials used in instructional delivery to suit a particular group of learning styles should be well accommodated by the size of classroom. This is to avoid wastage by supplying facilities that cannot be accommodated in the s pace provided. As different learning styles require different types of learning space, it is not cos $t$ effective to provide different classrooms for various pedagogical requirements. The simplest solution is to have flexible facilities (Furniture and Equipment) that can be transformed in the same classroom to suit the requirement of any collaborative learning/teaching styles to be adopted in the clas sroom.

\subsection{Consideration of indoor environm ental quality for such learning setting or layout}

A comfortable learning environment is a prerequisite in improving student achievement in the collaborative clas s room. The comfort factors in the clas sroominclude; lighting, acoustics, thermal and indoor air quality. Many studies have confirmed the positive effect of a comfortable clas sroom on students understanding and achievements [17; 18; 31]. The res earch linking acoustics to learning outcomes in the classroomis reliable and credible, as high-quality acoustics are fundamental to good academic performance [36]. Moreover, accurate hearing is crucial to the s tudents' ability to absorb information. The ability to clearly hear and understand what is being verbally communicated is a prerequisite for effective learning. When this ability is impaired through unwanted noise, it will decrease students' performance. [9]. Poor indoor air quality in the learning environment can cause illnes s leading to absenteeis min school, and result in acute health symptoms which often decrease the students' performance [12]. Hence, the indoorenvironmental quality has a great impact on learning outcomes and should be considered when setting up the collaborative and interactive le arn ing environment.

\subsection{Analyse and establish the required geometrical configuration for the collaborative learning style}

The adopted learning styles, facilities and equipment re quirements, together with the consideration for comfort and classroom size should be examined carefully in order to establish the required geometric configuration for the collaborative learning style in the classroom. The type and nature of furniture and equipment has to be analysed thoroughly to provide a proper arrangement suitable for the adopted learning style. Clas sroo m seating arrangement remain s the core consideration in designing any collaborative learning environment. This is due to the fact that $\mathrm{d}$ iffe re $\mathrm{nt}$ collaborative learning styles require a varying level of student interaction, and as such, different seating arran geme n ts must be suited to their pedagogical activities.

\subsection{The allocation of required pedagogical tools, equipment and materials for each collaborative group}

Collaboration in the university clas sroomrequires the grouping of s tudents which will largely depend on the type and nature of the pedagogical activities required in the classroom. These groups will at times require some tools, equip ment and materials that will help in understanding a particular aspect of the course requirement. Tools such as software and equipment such as clickers, and materials and rough papers should be provided for each group in the clas sroom before students enter to participate in the collaborative session. 


\subsection{Grouping of students to suit the adopted collaborative style}

The grouping of students in the collaborative classroom to carry out any assigned task is one of the important characteristics in setting the collaborative classroomlayout. The responsibility of selecting the students lies with the instructor. The instructor will know the performance of every person in the classroomand can facilit a te that exc ellent students and academically poorer once will be mixed in each group. Thus, the main aim of collaboration is to provide the required avenue in which students will learn from each other. Group students are responsible for distributing any as signed task fairly amongst themensuring that each member contributes adequately. A student with leadership abilitie s should be included in each group to provide the best outcome.

\subsection{Com mencement of Collaborative and interactive learning activities}

When all the necessary arrangements in terms of space, furniture, equipment, materials, comfort and grouping are in place, the collaborative and interactive learning may begin. These processes should be monitored and supervised by the teacher who will then remain as facilitator throughout the session and the required collaborative learning style will then be delivered with very few problems.

\subsection{Review the Effectiveness of the Developed collaborative learning style and its Implementation}

The outcome of the collaborative learning activities will be reviewed after one or two lectures, which assess its effectiveness in relation to the provided strategies. The assessment result will enable any fault that has been identified to be corrected. This will strengthen the entire methodology and will result in delivering a better collab orative lea rn ing outcome.

\subsection{Recommend solutions to the documented problems and implement the reorganized strategy in the next meeting}

Solutions will be recommended to deal with the problems identified in the process of the en tire collaborative and interactive framework model implementation. Based on theserecommendations, the reorganized framework model will be reapplied again in subsequent lecture meetings. Thus, a perfect framework model for implementing collaborative and interactive learning will have been achieved. Figure 1 illus trates the logical steps in the collab orative and in teractive framework model.

\section{DISCUSSION}

Classroom comfort is the key to achieving optimum student performance. The need to ascertain the major considerations that are significant in student achievement in the university classroomcan never be over emphasized. The quality of the indoor environment, the physical set up of the classroom, the instructional equipment and technology, and an emerging teaching and learning pedagogy are the major factors affecting student performance in the university classroom. Figure 2 below illustrates the Relationship between various influential components of the university class room.

The indoor environmental quality including; thermal comfort, lighting, acoustics and indoor air quality has to be balanced with the student comfort requirement in order to create theenabling environment for educational activities that will eventually improve student learning and performance. This can be achieved by studying the existing indoor environmental conditions with the aim of as sessing meas ures of improvements.

The physical set up of the classroom including; geometric configuration, classroom size, furniture layout, and equipment have a great impact on student learning and learning styles [6]. There is a need for the provision of require d interior geometric configuration and furniture layout which is also dependent on the collaborative and interactive teaching/learning styles eng aged by the students and teachers in the classroom. Many styles of teaching/learning used in the university classroomhave been identified; it is impossible to have a single geometrical configuration to s uit all the existing learning styles. There is the need for the provision of flexible and recon figurable furniture in the clas sro om in order to suit any collaborative learning style that may be implemented. Furthermore, there is no common teaching/learning style suitable for all universities; every university will have a different approach to collab ora tive an d interactive learning depending on the nature of the course in which that particular style needs to be used. Hence, the teaching/learning style is a major factor that will dictate the type of geometrical configuration to be adopted in collaborative clas srooms.

The frequent technological developments in the world create the challenge of providing modern instructional technology which can deliver the required flexibility in all activities in the collaborative and interactive classroom. The univers ity classrooms requires Internet access for research, distribution of multimedia curriculumonline, access to digital libraries, distance education courses and remote collaborative tools like videos, live video broadcast, desktop videoconferencing and 3D modelling [15]. Moreover, multimedia tools like tele-education systems guarantee wider access to education and support for lifelong learning, due to the power of live instruction in focussing studen $t$ atten tion 
more efficiently than static materials [45]. Hence, this system allows teachers and students in different locations to participate in clas sroom teaching through the mu ltimedia communication systems .

Identify the collaborative learning style to be adopted in the classroom

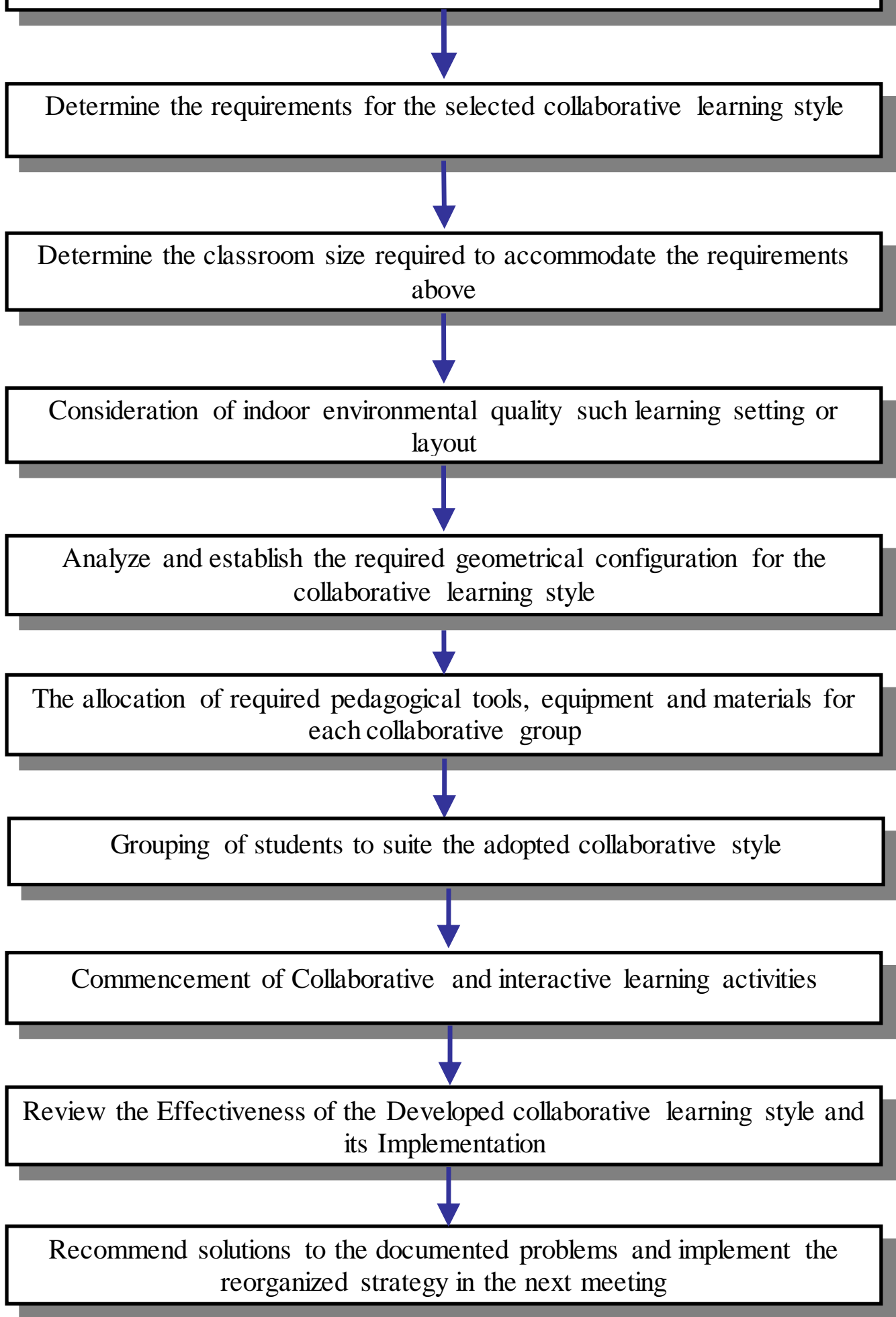

Figure 1: Framework Model for Implementing Collaborative and Interactive Learning in the University Clas sroom 


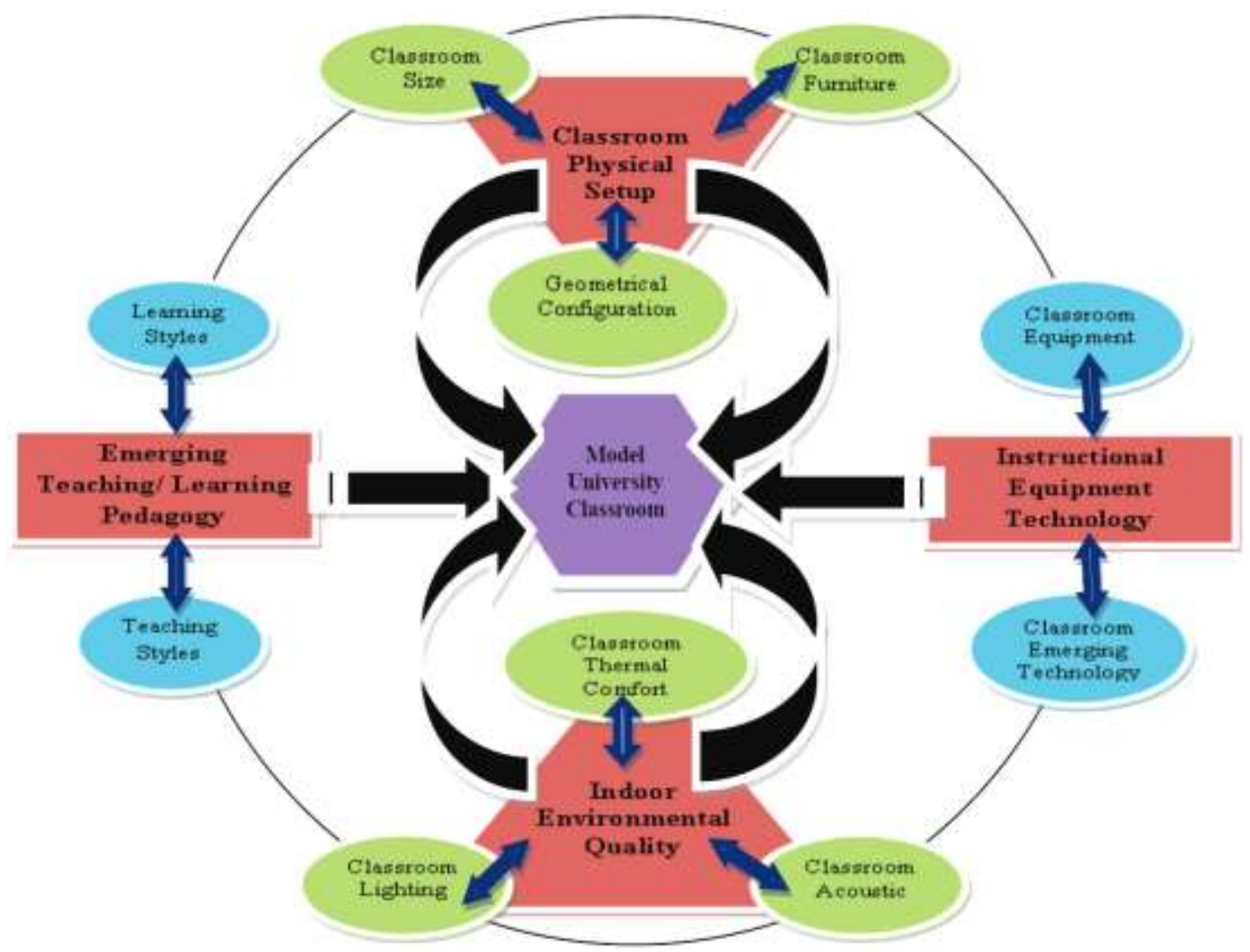

Figure 2: The relations hip between various influential components of the university classroom

\section{CONCLUSION}

This study of the framework model for the implementation of Collaborative and Interactive Le arning in the university clas sroomanaly ses the university classroom and ascertains the major influential factors affecting student performance in this environment. The study confirms that, the physical set up of the classroom; theindoor environmen tal quality, the instructional equipment and technology, and the emerging teaching/learning pedagogies are the four major in fluential factors affecting student performance and their learning and also the teaching styles in the classroom. It has been demons trated that, there is theneed for the provision of flexible and reconfigurable furniture in the clas sroom which will accommodate any collaborative learning style implemented. The study has established a model framework for implementing collaborative and interactive learning. This paper is part of a larger study of collaborative and in teractive learning in the university clas sroom.

\section{RECOMMENDATIONS}

More research is required to establish suitable and flexible furniture that can be reconfigured to suit any collabora tive learning style that will be adopted in the university clas sroom.

\section{REFERENCES}

[1] ADB (2009) "Good Practice in Information and Communication Technology for Education" Asian Development Bank (ADB) publication, focus on education series. http://beta.adb.org/publications/good-practice-information-andcommunication-technology-education Accessed on 5th March, 2012

[2] AFC (2010) “Access Flooring” Access Flooring Company, www.accessflooring.comaccessed on 15-may 2010

[3] Benjamin S. Et al (2000), "Classroom Acoustics: A source for Creating Learning Environments with Desirable Listening Conditions", Acoustical Society of America. http://asa.aip.org/classroom/booklet.html. Accessed on 13 $10-2009$

[4] Benya J. R (2001), "Lighting for Schools", National Clearinghouse for Educational Facilities 1090 Vermont Avenue, N.W., Suite 700, W ashington, D.C. 20005-4905 888-552-0624 www.edfacilities.org

[5] businessbalss (2010) "kolb learning styles" http://www.businessballs.com/kolblearnin gstyles.htm Accessed on 26th March, 2010 
[6] Callahan J., (2004), "Effects of Different Seating Arrangements in Higher Education Computer Lab Class rooms on Student Learning, Teaching Style, And Clas sroom Appraisal", Masters of Interior Design Thesis, University of Florida

[7] Dillenbourg, P., Betrancourt, M., and Schneider, D., Gurtner, J. L. (2005) "Technologies for Vocational Tra in ing" Propos al presented to KTI/CTI, Scientific committee of BBT/Switzerland for a Lead ing House

[8] Durfee, E.H., Lesser, V.R. \& Corkill, D.D. (1989), Cooperative Dis tributed Problem Solving, In: Kumar, V.S., "Computer-supported Collaborative Learning: Issues for research", http://www.cs.usask.ca/grads/vsk719/academic/890/project2/node2.html, accessed on 14th October, 2009

[9] Earthman, G. I., (2002), "School Facility Conditions and Student Academic Achievement", Los Angeles, CA: UCLA's Institute for Democracy, Education, \& Access (IDEA).

[10] Ed Young, et al. (2003), “Do K-12 School Facilities Affect Education Outcomes?” The Tennessee Advisory Commis sion on Inter-governmental Relations, Staff Information Report, www.state.tn.us/tacir

[11] Emmons M., and Wilkins on F. C., (2001), "Designing the electronic classroom: applying learning theory and Ergonomic design principles”'Library Hi Tech, Volume 19, Number 1, PP 77-87, MCB University Press

[12] EPA, (2003), “Indoor Air Quality and Stu dent Performance”, Indoor Environment Divis ion Office of the Radiation and Indoor Air; 402-K-03-006, www.epa.gov/iaq/schools

[13] Felder R. (2010) "Student-Centered Teaching And Learning" http://www4.ncsu.edu/unity/lockers/users/f/felder/public/Student-Centered.html Accessed on 12th March, 2010

[14] Franklin H. (2008), "Patterns For Small Learning Communities at the Elementary Level: The "L" Shaped Classroom", Article Published At Www.Schoolfacilities.Com,

[15] Gillian M. E. (2001), "The Impact of ICT on Schools: Classroom Design and Curriculum Delivery”, A Study of Schools in Australia, USA, England and Hong Kong, 2000, www.marsden.school.nz

[16] Gokhale A. A., (1995) “CollaborativeLearning Enhances Critical Thinking” Journal of Technology Education Vol. 7 No. 1

[17] Hes chong Mahone Group (1999), "Daylighting in Schools: An investigation into the relationship between daylig ht and human performance", Detailed Report, Fair Oaks, CA. www.h-m-g.com

[18] Hes chong Mahone Group (2003), "Windows and Clas srooms: A Study of Student Performance and the Ind oor Environment", Detailed Report, Fair Oaks, CA. www.h-m-g.com

[19] Janet M. J. (1999), “Teaching for Tomorrow the Changing Role of Teachers in the Connected Clas sroom”, EDEN, Open Class room Conference - Balatonfüred

[20] Kokkelenberg E. C., Dillony M., and Christy S. M (2005) "The Effects ofClas s Size on StudentGrades at a Public University" International Programs Visiting Fellow Working Papers Cornell University ILR USA. http://digitalcommons.ilr.cornell.edu/intlvf/6

[21] Kolb, DA (1976), “learning styles inventory: Technical manual”, McBer and Company, Boston.

[22] Kruger E. L. and Zannin P. H. T., (2004), “Acoustic, thermal and luminous comfort in classrooms", Build ing and Environment 39 (2004) 1055 - 1063, www.elsevier.com/locate/buildenv

[23] Leidner D. E., and Fuller, M. (1997) “Improving student learning of conceptual information: GSS supp orted collaborative learning vs. individual constructive learning” Decis ion Support Systems, 20 (2), pp. 149-163.

[24] Leinonen P. (2007) "Interpersonal Evaluation of Knowledge in Distributed Team Collaboration" Academic Diss ertation, Faculty of Education, Department of Educational Sciences and Teacher Edu cation, University Of Oulu. Oulu University Pres s, Finland.

[25] Littleton, K., \& Häkkinen, P. (1999) "Learning together: Understanding the processes of computer-based collaborative learning” In P. Dillenbourg (Ed.), Collaborative learning: Cognitive and computation al ap proach es (pp. 20-31). Oxford, UK: Pergamon.

[26] Mäkitalo-Siegl, K., Zottmann, J., Kaplan, F., and Fischer, F. (2010) "Classroom of the Future: Orchestrating Collaborative Spaces", 1-12; Technology Enhanced Learning Sense Publishers. Rotterdam, http://www.sensepublishers.com

[27] McCorskey, J. C., and McVetta, R. W. (1978) “Clas sroomSeating Arrangements: Instructional Co mmu nication Theory versus Student Preferences” Communication Education, Volume 27, 
[28] McCoy M. R., (2006), "Teaching style and the application of adult learning principles by police in structors", An International Journal of Police Strategies \& Management, Vol. 29 No. 1, pp. 77-91, Emerald Group Publis hing Limited

[29] Mendell, M.J., and Heath G.A.,, (2005), "Do indoor pollutants and thermal conditions in schools influence student performance?" A critical review of the literature. Indoor Air 15:27-52.

[30] Muir, D. J., (2001), “Adapting Online Education to Different Learning Styles” National Education al Co mputing Conference, "Building on theFuture" July 25-27, 2001, Chicago, IL

[31] New Building Institute (2002), "Daylighting in Schools, Additional Analyses", California Energy Commission PIER Programwww.newbuildings.org/PIER.

[32] Niemeyer, D. (2003), "Hard Facts on Smart Classroom Design: Ideas, Guidelines, and Layouts", the Scarecrow Press, Inc. Lanham, Maryland United State of America.

[33] Project FROG team(2008), “The Class roomof the Futureat Green building”, Acuity Brands Ligh ting, Inc. One Lithonia Way, Conyers, GA 30012, www.AcuityBrandsLighting.com

[34] Project, C., (2008) "Collaboration and Learning: Managing Groups" Retrieved from the Connexions Web site: http://cnx.org/content/m16597/1.1/ on 10th October, 2010

[35] Santo, S. (2010) "Learning styles and personality" Vermillion, SD: University of South Dakota School of Education; Available at http://people.usd.edu/ ssanto/styles.html, Accessed on 12th March, 2010

[36] Schneider, M. (2002), "Do School Facilities Affect Academic Outcomes", NationalClearinghouse for Educa tional Facilities 1090 Vermont Avenue, N.W., Suite 700, Washington, D.C. www.edfacilities.org

[37] Shaughnessy, R.J., Haverinen-Shaughnessy, U., Nevalainen, A., and Moschandreas, D., (2006), “A Pre liminary Study on the Association between Ventilation Rates in Classrooms and Student Performance", Indoor A ir, 16 (6), pp 465-468.

[38] Smith P. And Dalton J. (2005), "Getting to grips with learning styles" A National Vocational Education and Training Research and Evaluation ProgramReport (NCVER)

[39] Stahl, G., Sumner, T., and Repenning A. (1995) "Internet Repositories for Collaborative Learning: Supporting both Students and Teachers" InternetRepositories for Collaborative Learning: Supporting both Students and Te ac hers, Proceedings of the Computer Support for Collaborative Learning, Bloomington, Indiana,

[40] Swinton, L. (2004), "Honey \& Mumford Learning Style Questionnaire." Mftrou.com. http://www.mftrou.com/honey-mumford.html

[41] Thibault, L. L. (2005), “Implementing Classroom Acoustics Standards: a Progress Report”, US Access Board. http://www.armstrong.com/commceilingsna/article19166.html. Accessed on 13 October 2009

[42] Tocco P. (2009), “The Ideal Classroom: Technology \& Tradition” Educational Psychology educ. 260, Howard County Community College, www.baltimorphosis.com

[43] Upchurch, B. L., and Thai, C. N. (2002) "Interactive Classroom for Experiential and Collaborative Learning" Proceedings of the 2002 American Society for Engineering Education Annual Conference \& Exposition.

[44] Wargocki P. and Wyon D. P., (2007), "Indoor Environmental Effects on the Performance of School W ork by Children",(1257-TRP), Final Report

[45] Yuanchun S. Et al (2003), “The Smart Classroom: Merging Technologies for Seamless Tele-Education”, Published by the IEEE CS and IEEE ComSoc, http://computer.org/pervasive 